\title{
Mehmet Âkif Ersoy'un Şiirlerinde Telkin, Tenkit, Telmih Unsuru Olarak Mekân ve Tasvirler
}

\author{
Özlem FEDAİ *
}

Öz

Bir edebî eserin hayatla olan bağını güçlendiren önemli unsurlardan biri de mekân ve onun tasviridir. Edebi eserlerde mekân ve tasvir, metnin gerçekle olan bağını yansıtması açısından önemli olduğu kadar sanatçının iç dünyasının dışavurumuna katkı sağladığı kadar eleştirileri ve değerlerinin aktarılmasına hizmet etmesi açısından da önemlidir.

Osmanlı Devletinin son zamanlarından Türkiye Cumhuriyeti’ne geçiş sürecine kadar şiirleriyle bir değer değişimine, kültürel kırılmaya şahitlik eden Mehmet Âkif Ersoy (1873-1936)'un, şiirlerinde de mekân, hem şairin aidiyet alanı olarak gördüğü ve sahiplendiği Müslüman Şark toplumunun gerçeklerini eleştirerek değiştirmek amacıyla yansıttığı bir projektör hem de şairin iç dünyasının/davasının taşıyıcısı durumunda olmuştur.

Bu çalışmada ana hatlarıyla İslâm kültür ve medeniyetine sahip çıkma davasının aksiyoner şairi Mehmet Âkif'in şiirlerinde tespit edilen mekânlar üç ana başlık altında toplanmış; özelden genele bu mekânlar üzerinden yansıtmaya çalıştıkları değerlendirilmiştir. Şairin şiirlerindeki mekânlar; kutsal ve idealize mekânlar, natüralist bir nazarla tasvir ettiği "kusurlu mekânlar" ve İslâm ülküsünün taşıyıcısı durumundaki Müslüman Şark coğrafyası olarak sınıflandırılabilir. Sonuç olarak şairin şiirlerinde anlattığı tüm mekânları; Müslümanlara sorumluluklarını hatırlatma, İslâm değerlerini telkin etme, onları eleştirerek dönüştürme amaçlarını gerçekleştirmek için tercih ettiği saptanmıştır.

Anahtar Kelimeler: Mehmet Âkif Ersoy, Safahat, mekân, tenkit, telkin, telmih.

\footnotetext{
* Prof. Dr., İstanbul Medeniyet Üniversitesi Eğitim Bilimleri Fakültesi Türkçe ve Sosyal Bilgiler Eğitimi Bölümü, İstanbul, Türkiye.

Elmek: ozlem.fedai@gmail.com,ozlem.fedai@medeniyet.edu.tr https://orcid.org/0000-0001-7726- 4096.
} 


\title{
Space And Descriptions As A Feel Of Suggestion, Criticizm, Indoctrination In The Poems Of Mehmet Âkif Ersoy
}

\begin{abstract}
One of the important elements which strengthen the bond of a literary work with life is the place and its description. In literary works, the concepts of space and description have special significance in terms of reflecting the connection of the text with reality, as well as contributing to the expression of the artist's inner world, as well as conveying his criticisms and values.

In the poems of Mehmet Âkif Ersoy (1873-1936), who witnessed the value change and cultural break with his poems from the last years of the Ottoman Empire to the transition period to the Republic of Turkey, the concept of space was also reflected in his poems, acting both as projector and the carrier of the poet's inner world, combined with the goal of criticizing, changing the realities of the Muslim Orient society, which he himself sees as the place of belonging.

In this study, the places identified in the poems of Mehmet Âkif Ersoy, the action poet embraced with the goal of protecting the Islamic culture and civilization, are examined under three main headings; it is evaluated that they try to reflect from particular to general through these spaces. The places in poet's poems can be ranged from the sacred, idealized places to the "imperfect places" which the poet describes with a naturalist view and lastly the Muslim Orient geography, representing the carrier of the Islamic ideal. It is reached to the conclusion that Mehmet Akif Ersoy preferred all the places in his poems with an intention of reminding the responsibilities of the Muslims in the society, inculcating Islamic values and transforming them by criticizing.
\end{abstract}

Keywords: Mehmet Âkif Ersoy, Safahat, place, criticism, suggestion, reference. 


\section{Giriş yahut Mekân ve Tasvirin Anlamı}

Batı edebiyatında, edebieserlerdemekân vetasvirinişlevinin anlaşı1ması, "mekân" ve insan psikolojisinin bağının kavranmasıyla doğru orantılıdır. Mekânın başarılı tasviri, sanatçının iç ve dış dünyasının, değerlerinin okura doğru aktarılması açısından oldukça önemlidir. Okurun olay örgüsünün içine çekilmesinin ve eserin yaratacağı etkinin biraz da başarılı tasvirle mümkün olabileceğine inanan sanatçılar gerçekçi tasvire yoğunlaşmışlardır. Olayın ve şahısların ön planda olduğu edebi eserlerde mekân ve tasvirler, eserin gerçekle olan bağını, olabilirliğini yansıtır.

Şerif Aktaş'ın ifadesiyle mekân, "vaka zincirinde ifade edilen hadiselerin sahnesi durumundadır." (Aktaş, 1991: 141). Mekânın gerçeğe yakın tasviri, olayların aydınlığa kavuşmasına hizmet ettiği gibi sanatçının ve eserin kahraman/ larının iç dünyalarının açığa çıkmasına da hizmet eder. Ayrıca "Olayların geçtiği çevrenin tasvir edilmesi sadece anlatı sisteminin 'inşa' edilmesi açısından değil, okuyucu açısından da gereklidir. Böyle bir imkânla okuyucu, olayların mahiyetini anlamakta zorlanmaz." (Tekin, 2011: 130)

Kimi mekânların sanatçı gözüyle ayrıntılı tasviri, sanatçının aidiyet hissettiği toprağa, cemiyete, millete veya ümmete dair fikir ve endişelerin yansıtılması amacına hizmet eder. Sanatçıların yapacakları telkin veya ikazlar için vesile oluşturan mekânlar, somut, kutsal, ideal/idealize mekânlar olabildiği gibi natüralizmin aşırı gerçekliği ile mercek altına alınıp olumsuzlama ile anlatılan "kusurlu mekânlar" da olabilir.

Mekân üzerinden iç dünyasının, anılarının, bireysel ya da toplumsal endişelerinin kapılarını açan sanatçı; onu var eden unsurları, poetik ve politik duruşunu da sergilemiş olur. Zira "Mekân, insanın arzularının bir ifadesi olabilir. Eğer mekân olarak tabiat seçilmişse, burada arzular tabiata yansımış 
olabilir. (...) Gene mekân, ferdin hiçbir şekilde değiştirme imkânı bulamadığ fizikî veya sosyal şartlar şeklinde görüldüğünde eserde kuvvetli bir tayin edici rol oynayabilir". (Wellek-Varren, 1993: 196)

Mekânın edebi eserlerde mutlaka somut olması gerekmez; olayların cereyan ettĭgi /edeceği çevre, "hayali" veya "ütopik" (idealize edilerek tasarlanmış) de olabilir. (bkz. Tekin, 2011:149). Betimledikleri bu mekânlar üzerinden sanatçılar, inanç, değer ve eleştirilerini yansıtıp idealleri için okura telkinlerde bulunabilir.

Mekânın "yansıtıcı (projektör)” işleviyle edebî eserde yer alması; sanatını "hakikat"leri anlatmaya adayan, İslâm medeniyeti davasını tüm Şark’a telkin etmeye çalışan Mehmet Âkif gibi sanatçılar açısından farklı bir öneme sahiptir. Mekâna tasvir yoluyla tutulan ayna/projektör, metnin derinlik kazanmasına, sanatçının eleştiri ve telkinlerinin somutlaşmasını sağlamıştır.

Mekânın tasvir şekli sanatçının sanattan ne anladığını da sergiler. Raymond Weaver, tasvirin bir edebi eserde nasıl yapılması gerektiğini "hayal gücümüzün algılayabileceği ve ayrıntılarını âhenkli bir bütünde buluşturabileceği bir tarzda olmalıdır" (Weaver, 1991: 66) sözleriyle dile getirir.

Realist ve natüralist eserlerde -bilhassa romanlarda-, karakterin zihninin ve iç dünyasının okura açılmasında mekân tasvirinin işlevi yeri daha fazladır. Örneğin 19. yy Paris'inin yoksul işçi sınıfının yaşam kavgasını, alkol ve sefahate batmış hâllerini anlatan Emilé Zola, Meyhane (1877) romanında tasviri, yoğun bir sosyal yansıtıcı olarak kullanmıştır.

Tasvirler, bir eserde hem görsel bir dil malzemesidir hem de gerçeğin kendisini ima eden, aydınlatan, bu bakımdan da işlevsel olan ayrıntılar bütünüdür. Tasvir bir taraftan da sanatçının dünyayı algılayış biçimine 1şık tutan gerçeklik ölçütüdür. Bu sebeple birçok romancı ya da kuramc1; tasvirin, okurun zihninde yazarın bırakacağı gerçeklik anlayışının inşasına hizmet etmesi gerektiğinin altını çizer. Örneğin Allain-Robbe Grillet, “tasvirlere 
psikolojik, sosyal ya da kültürel anlamların yüklenmesi yerine (onların) daha gerçekçi bir dünyanın inşası için kullanılması gerektiğini savunur." (Fowler, 1991: 28).

\section{2. İslâm Davasına Adanmış Bir Şairin Şiirlerinde Mekân}

Hasan Boynukara, “Tasvirin psikolojik düzeyinden de söz edilebilir. Örneğin, sıklıkla rastladığımız gibi, dışarıdaki bir fırtına, içerdeki bir fırtınaya işaret edebilir. Tasvirin olay örgüsüyle metaforik ve metonomik bağları olabilir. Çiçeğin koparılması, bir genç kızın ümitlerinin yok olması anlamına gelebilir. Eleştirmen ya da okuyucu tamamen dekoratif amaçlı bir tasvirde pekâlâ farklı ilişkiler kurabilir.” (Boynukara, 2007: 293) diyerek tasvirin psikolojik işlevinden söz eder ki Türk edebiyatında Tanzimat'tan itibaren bu durumun birçok örneğine rastlanabilir. Örneğin Tevfik Fikret, "Sis" (1902) şiirinde; padişaha/yönetime duyduğu büyük öfkeyi, içinde "kaçış" psikolojisiyle mekâna/ İstanbul'a yansıtmış; âdeta iğrenircesine şehrin kapalı ve açık tüm mekânlarına kara bir tasvirle öfkesini kusmuştur. İstanbul, bu şiirde; şairin içinde kopan firtınayla "Marmara'nın mâi der-âguşu içinde ölmüş gibi dalgın uyuyan tûde-i zinde" veya "fâcire-i dehr" olarak betimlenir (Bkz. Tevfik Fikret, 18 Şubat 1317/3 Mart 1902; Tevfik Fikret: 1327: 295-299). Denizinden, göğüne, camiinden, medresesine ve türbesine, saraylarından, han ve hamamlarına dek -birçoğu tarihi olan- şehrin tüm mekânlarını, “ölü yığın”’n birer parçası olarak gören Fikret, mekânın her bir parçasını bakımsızlık, çirkinlik ve pislik içinde görerek tasvir eder.

Fikret "Sis"te mekâna ve nesnelere psikolojisi nedeniyle olumsuz yüklemeler yapmıştır. Toplumuna yabancılaşmış, ona aidiyet hissetmeyen şair, şehri betimlerken de "düzeltme", "değiştirme" kaygısı taşımamış; yıkıcı bir tavır takınmıştır. Ancak onunla zit kutupta yer alan Mehmet Âkif' in ise, toplumun gerçeklerini yansıtırken İstanbul'a tepeden bakıp onu aşağılamamış; bakımsız arka sokaklarından geçerek yoksul hânelerini ziyaret edip halkı ile 
hemhâl olmuştur. Yoksul haneleri tasvir ederken bile yapıcı, onarıcı bir tavır sergilemiş; yanlış eğilimlerde olan insanlarını eleştirmiştir.

Tanzimat'ın önde gelen şairlerinden Namık Kemal de duruşu ve davasıyla olduğu kadar, şiirlerindeki telkin ve eleştirilerde tasvirden yararlanma biçimiyle Âkif'in öncülü olmuştur. Her ne kadar şiir dünyaları farklı olsa da İslâm'ın değerlerini Batı'ya karşı savunmak konusundaki hassasiyetleri örtüşen Namık Kemal gibi Âkif de şiirlerinde, bugünün hâllerini tasvir eder, geçmişin şanlı günlerine telmihler yapar. Namık Kemal de toplumu aydınlatmak isteyen bir şair tavrıyla "bir kısım şiirlerini dinî esaslara dayandırarak Kur'an ve hadislerle desteklemiştir” (Tuncer, 1992: 90). Ayrıca "Hürriyet Kasidesi" başta olmak üzere şiirlerinde milletini "silkiniş"e davet etmiş; makalelerinde toplumun değerlerini savunmuştur. “Hürriyet Kasidesi”nde Osmanlı tarihinden örnekler vererek milleti yeniden özüne döndürmeye çalışan Kemal'in ruh hâliyle Âkif' in, birçok şiirinde İslam tarihinden örnekler vererek yaptığı “öze döndürme” çabaları benzerlik gösterir. Ayrıca Kemal'in de tıpkı Âkif' in Fikret'e verdiği cevap gibi, Fransız filozof Renan'ın "İslam dininin ilerlemeye engel” olduğu konusundaki görüşlerine Renan Müdafaanamesi'ni yazarak sert bir cevap verdiği hatırlanmalıdır (kitap halinde basımı 1908) (Akyüz, 1986: 60; Tuncer, 1992: 94).

"Namık Kemal'in şiiri ile şiir hakkındaki teorik görüşleri arasında büyük bir fark olmasına rağmen Âkif'in şiiri ile şiir hakkında ortaya koyduğu görüşler arasında hemen hemen hiçbir çelişkinin olma"dığını (Gökçek, 2007: 43) belirten Fazıl Gökçek, iki şairin reel dünyaya karşı geliştirdikleri tavrın aynı oluşuna işaret eder ki sergiledikleri bu tavırda, reel tasvir ve telmihler "silkinişe davet" için önem arz etmektedir.

Âkif' in sanatının en mühim vasıfları, "cemiyetin hayatını terennüm etmek, mahallî bir edebiyat yapmak" şeklinde özetlenebilir. Sezai Karakoç, Âkif' in şiirinin iki ana unsur üzerinde şekillendiğini, bu unsurlardan ilkinin İslâm, ikincisinin realite olduğunu dile getirir (Kararkoç, 1974: 36). Bu iki 
unsur, şairin eleştirileriyle, manzaraya dışardan değil içerden bakan tasvir ve telkinleriyle örülerek şiirlerinde yer almıştır.

Şairin birçok şiirinde mekân tasviri, reel dünyayı tüm çılaklığıyla gözler önüne sererken, "ideal"i yeniden inşa etmeye davet amacıyla yapılır. "Hasta", "Küfe", "Seyfi Baba", "Mahalle Kahvesi” vb. şiirlerinde görülebilen mekân tasvirleri genelde bu amaca hizmet eder. Tasvir bu şiirlerde, gerçekçi bir dünyayı yansıtmış ve ideal olanı inşa etmenin peşinde olmuştur. Âkif, Safahat'taki birçok şiirinde "tıpkı Emile Zola'nın natüralist romanlarındaki gerçekçilikle tasvirler yap"mış; âdeta eserini natüralist bir romana yaklaştırmıştır (Bkz. Fedai, 2008: 680).

Âkif’in şiiri, yansıttığı "gerçeklik” ve "güncellik”le, Sezai Karakoç’un ifadesiyle bir "günlük" (jurnal) durumundadır. Ancak bu günlük, "bir şairin (ben)i etrafında toplanan eşya ve olayları anlatışının değil, bütün bir toplumun günlüğüdür” (Karakoç, 1974: 37). Safahat boyunca Âkif'in; şiirle, şairle, İslâm ve Batı dünyasıyla, Batı'nın "medeniyet” maskesi altında yaptıklarıyla hesaplaştığ düşünülecek olursa Karakoç’un hakl11ığ1 anlaşılır. İnci Enginün de "Meyhane ve kahve müdavimleri, camideki cemaat ve halk ile yakından teması olan Köse İmam ve vaizlerle Safahat İstanbul'un kalabalığını aktarır" (Enginün, 1997: 70) diyerek Karakoç’un sözlerini doğrular.

"Hasta”, "Küfe”, "Hasır”, "Meyhâne”, "Bayram”, "Seyfi Baba", "Mahalle Kahvesi”, "Köse İmam”, “Âmin Alayı” vb. şiirlerinde, şairin şiirinin bir "jurnal” durumunda olduğunu, günlük sıradan hadiselerden, gözlemlerden şiir çıkardığını, reel dünyayı en çarpıcı şekilde yansıtmak düşüncesiyle tasviri kullandığını görürüz.

Mehmet Âkif Ersoy, “i’lâ-yı kelimetullah” davasına gönül vermiş bir şair olarak; "İslâm kültür ve medeniyeti”ni, "tek dişi kalmış canavar" olarak gördüğü Batı’nın tahakkümüne karşı korumak düşüncesiyle şiirlerini yazmıştır. Ayrıca şair, Şark’ın kendi içine düştüğü fikir ayrılıklarıyla yaşadığı açmazları tahkiye etmiş; bunun için de mekân tasvirinden istifade eder. Estetik 
haz verme düşüncesi taşımadan, gür bir erkek sesiyle haykıran "tebli ̆̆" ve "eleştiri" niteliği taşıyan şiirleriyle; yaşadığı toplumun ve tüm Müslüman Şark'ın gerçeklerini deşifre etmiştir. Bu yüzden de mekân tasvirleri, şairin şiirlerinde ayna, büyüteç hatta projektör işlevi görmüştür.

Âkif'in şiirlerindeki mekânlar; bakımsızlıkları veya barındırdıkları olumsuzluklarla günlük hayatın gerçekliklerinin parçası durumundaki "somut mekânlar" olabildiği gibi, şairin ülküsünün yansitıcısı durumundaki "kutsal", "ideal" ve "idealize" mekânlar da olmuştur.

"Şark coğrafyası"nı soyut, açık hatta algısal bir mekân olarak yansıtan Âkif, Tevfik Fikret’le "Tarih-i Kadim” (1905) şiiri üzerinden giriştiği kavgada da aslında Şark-İslâm coğrafyasının değerlerini gür bir sesle savunmuştur. Şairin bu güçlü erkek sesiyle giriştiği savunma, Cumhuriyet ideolojisinin ilk döneminin bazı şair ve eleştirmenleri tarafından "yobaz" bir "cami hocası" olarak anılmasına sebep olmuştur ${ }^{1}$. İnançlı bir dava adamı olarak şairin hakkını ölümünden sonra teslim eden Orhan Seyfi Orhon gibi şairler de olmuştur ${ }^{2}$ ki Orhon'un belirttiği gibi “fikirlerini şiire dönüştüren” (Çantay, 1966: 306) Âkif, mekân ve tasviri de bu amaç için başarıyla kullanmıştır. Bu noktada "Özellikle 19. yüzyılda yani fotoğraf ve sinemanın henüz ortaya çıkmadığı dönemde bir manzarayı ya da bir insanı sözcüklerle tasvir ederek görsel etkiler yaratmayı amaçlayan edebi anlayış sonraki dönemlerde sürmüş ve Safahat gibi şiirsel metinleri de etkilemiştir” diyen (Uğur, 2016: 416) Veli Uğur'un tespiti haklıdır.

Âkif'in, şiirlerinde gözlem kabiliyetinin güçlü olduğu kadar kurgu kabiliyetinin de yüksek olduğunu söyleyebiliriz. Şiirlerinde betimlediği bazı

1 Cumhuriyet yıllarında Yusuf Ziya Ortaç Âkif hakkında "Onun eserini okuduğumuz zaman nelerden kurtulduğumuzu anlıyoruz. (...) Onun istediği kendi fikir terbiyesinden doğan bir şeriat dünyasıydı" derken (bkz. Hasan Basri Çantay, 1966: 382-383); Şükûfe Nihal, Mehmet Âkif için: "Âkif, muayyen bir sınıfın şairi değildir. Ben, onda bir halk şairi vasfını da pek göremiyorum. O, ümmetçi bir adamdır. En karakteristik tarafı koyu bir din adamı oluşudur. Safahat’ı baştanbaşa karıștırınız her fikirde her mevzuda hep Allah hep Nebî” demiștir. (Çantay, 1966: 376-380).

Nurullah Ataç ise Âkif'i bir şair saymamış; “Âkif' in bir insan olarak kıymeti ne olursa olsun, bir şair sayılması hayli zor işlerdendir. Hele onda fikir aramak fikre hürmetsizlik olur. Din şairi, din filozofu değil, mahalle kahvesi hatibi” diyerek Cumhuriyet'in ilk on yılında karalamıştır. (Çantay, 1966: 361).

2 Örneğin, şairin ölümü ardından Orhan Seyfi Orhon, Tan gazetesinin 25 Haziran 1936 tarihli sayısında yazdığı yazıda; “(...) Türk edebiyatına hakikî erkek sesini o getirdi. Dar bir kafes içinde hülyalarını şakıyan Türk şiiri, hayatın sesini onun feryatlarıyla bize duyurdu. Alev gibi çırpınan bir kalbin içinden geçerek fikrin nasıl şiir olabileceğini ilk defa o gösterdi” (Çantay, 1966: 306) sözleriyle şairin hakkını teslim etmiştir. 
mekânları orada vakit geçirmiş birinin gözünden tasvir ettiği (Süleymaniye Camii, Fatih Camii, mahalle kahvesi, Seyfi Baba'nın evi vb.) görülmekte iken, bazı şiirlerinde tasvir ettiği mekânları duyumları yoluyla, kurgulayarak tasvir etmiştir. Bu sebeple şiirlerinde "somut" mekânlar"'n olduğu söylenebileceği gibi, algısal, idealize edilmiş mekânların olduğu da söylenebilir. 1914 sonlarında Harbiye Nezareti'nin verdiği görevle Berlin'de olan Âkif,'in Çanakkale Savaşı sürerken, sadece gazetede okuduğu haberlerden, duyduklarından hareketle "Çanakkale Şehitlerine" şiirini yazdığı düşünülecek olursa, şairin görmeden tüm ayrıntısıyla yapabildiği bu tasvir, topraklarına karşı hissettiği aidiyetle açıklanabilir:

"Yerin altında cehennem gibi binlerce lağam;

Atılan her Iağamın yaktığı: Yüzlerce adam.

Ölüm indirmede gökler, ölü püskürmede yer;

O ne müdhiş tipidir: Savrulur enkâz-1 beşer...

Kafa, göz, gövde, bacak, kol, çene, parmak, el, ayak,

Boşanır sırtlara, vâdîlere, sağnak sağnak.

Saçıyor zırha bürünmüş de o nâmerd eller

Yıldırım yaylımı tûfanlar, alevden seller

Veriyor yangını, durmuş da açık sînelere,

Sürü hâlinde gezerken sayısız tayyâre .

Top tüfekten daha sık, gülle yağan mermîler...

Kahraman orduyu seyret ki bu tehdîde güler!"

(Ersoy, haz. Düzdağ, 1999: 386)

Mehmet Kaplan da şairin söz konusu şiirinde, savaşın hareketli atmosferini göze hitap eden, film sanatına has unsurlarla başarıyla tasvir ettiğini dile getirir:

"Âkif, şiirinde Çanakkale Savaşı'nı geniş bir "tablo" şeklinde ele alır. Burada gerçekten "resim sanatına has", göze hitap eden unsurlar önemli bir yer tutar. Biz şiiri okurken adeta bir savaş tablosunu, daha doğrusu bir savaş 
filmini seyreder gibi oluruz. Zira burada sadece tablolarda olduğu gibi "statik bir manzara" değil, film sanatına has bir "hareketlilik" söz konusudur. Şair bu "hareketlilik"i mısraların arka arkaya sıralanışından faydalanarak temin eder. Film şeridinde olduğu gibi her mısra, vakanın ayrı bir görüntüsünü verir.” (Kaplan, 2014: 178-179)

Mehmet Âkif, eleştirel bir gözle kaleme aldığı şiirlerinde önce cemiyette gördüğü problemi katı bir hakikatle sergilemiş ardından düzeltilmesi için yapılması gerekenleri izah/ nasihat etmiştir. Bunun için kimi zaman Kur'an-1 Kerim'den, İslâm tarihinden, dört Halife'nin ahlâkından örnekler vermiştir. Böylece İslâm dünyasında gördüğü fikir ayrılıklarını, mutad hale gelen uyuşukluk ve tembelliği, "kader” gibi kabullenilen fakirliğin nedenlerini şerh etmiş; bunlarla mücadele etmek için yapılması gerekenleri, yöneticilere ve halka düşen görevleri inançlı bir aydın olarak izah eder.

Âkif, şiirlerinde kimi zaman, "anılaşmış", "anlam üreten” ve şairin iç dünyasını yansıtan "algısal mekânlar”a da yer vermiştir. "Algısal mekânlar kişi-yer ilişkisini sorunsal açıdan yansıtan, dönüştürülmüş anılaştırılmış yerlerdir; topografik bir yer değil, anlam üreten, anıları barındıran kişinin iç dünyasını yansıtan bir değerdir" (Korkmaz, 2017: 13) Camiler ("Fatih Camii”, "Süleymaniye Camii”) şair için bir yönüyle "kutsal, ideal ve idealize mekânlar" iken diğer yönüyle uzun yıllar kendisi için taşıdıkları ve ürettikleri anlam ile aynı zamanda "algısal" mekânlardır.

Ayrıca yoksul sokaklar, evler de şairin empati kurduğu, yoksulluklarını yansıttığı algısal mekânlardır. "Seyfi Baba" adlı manzum hikâyesinde, İstanbul'un yağmurdan göle dönmüş yoksul arka sokaklarından, taşları oynamış kaldırımlarından âdeta yüzerek geçtiğini söyleyen şair, birbirinden güç alarak ayakta kalan fukara, ahşap evlerini tasvir ederken realist gözlemleriyle bizi âdeta bir romanın sayfalarında gezdirir gibidir. Şairin yaşadığı zaman diliminde halkın içinde bulunduğu durumla hemhâl olarak gözlem ve tasvir yaptı̆̆ 1 şiirde dikkat çeker: 
"Sopa sağ elde, kırık camlı fener sol elde;

Boşanan yağmur iliklerde, çamur tâ belde.

Hani, çoktan gömülen kaldırımın, hortlayarak;

"Gel!" diyen taşları kurtarmasa, insan batacak.

(...)

Çifte sandal, yüzüyorduk; o yüzer, ben yüzerim.

(...)

Kâh olur, kör gibi çarpar sıvasız bir duvara;

Kâh olur, mürde şuâ'âtı düşer bir mezara;

Kâh bir sakfı çökük hânenin altında koşar;

Kâh bir ma’bed-i fersûdenin üstünden aşar;

(...)

Gecenin sütre-i yeldâsını çekmiş, üryan ,

Sokulup bir saçağın altına gûyâ uyuyan

Hânüman yoksulu binlerce sefîlân-1 beşer;

Sesi dinmiş yuvalar, hâke serilmiş evler;

Kocasından boşanan bir sürü bîçare karı;

Evi sırtında, sokaklarda gezen âileler!"

(Ersoy, haz. Düzdağ, 1999: 60-61)

Fakirliğin altında beli bükülmüş sokaklardan geçerek hastalanan "Seyfi Baba"nın evine ulaşan şairin beni, yine gördüğü yoksulluk karşısında üzülerek bir sorumluluk hissiyle ortamı tasvir eder. Aslında sıkça geldiği ve bir aidiyet duyduğu Seyfi Baba'nın evini, "Şâir olsam yine tasviri olur bence muhâl/ O perîşanlığı derpîş edemez çünkü hayâl” (Ersoy, 1999: 62) sözleriyle ve derinden hissettiği üzüntüyle betimlemeye çalışır:

“Odanın loşluğu kasvet veriyor pek, baktım

Şu fener yansa deyip bir kutu kibrit çaktım 


\section{O zaman nim açılıp perde-i zulmet nâgâh}

Gördü bir sahne-i üryân-1 sefâlet ki nigâh"

(Ersoy, haz. Düzdağ, 1999: 62)

"Seyfi Baba" şiirinde, dış mekâna (İstanbul'un yoksul arka sokakları) ve iç mekâna (Seyfi Baba’nın evi) "fener" tutan Âkif, sokakları 1şı̆̆ı̆yla aydınlattığ bu "fener"e, tıpk1 realist yazar Stendhal'in "ayna" metaforuyla ${ }^{3}$ işaret ettiği (Bkz. Stendhal, 1973: 393) gibi metnine "yansıtma/aydınlatma" vasfını yükler. Böylece acı da olsa gerçekliği tüm yönleriyle tasvir eder. İşsiz oğlunun yerine dam aktarırken hastalanan yetmiş beş yaşındaki Seyfi Baba'nın evinde gördüğü yoksulluğun ardından topluma vereceği telkini de ihtiyarın ağzından aktarır: "Kim kazanmazsa bu dünyada bir ekmek parası: / Dostunun yüz karas1; düşmanının maskarası" (Ersoy, haz. Düzdağ, 1999: 63) "Seyfi Baba”da, sanatçı beninin bu yoksul evde geçirdiği zaman; o mekânın, şair için bir tür "algısal" mekâna dönüşmesine neden olmuştur. Gördüklerinden büyük üzüntü duyan şair, çaresizliğini betimlediği o mekânın ve Seyfi Baba'nın ardından; "Ya hamiyetsiz olaydım, ya param olsa idi" (Ersoy, haz. Düzdağ, 1999: 63) diye haykırmıştır.

"Kocakarı İle Ömer" şiirinde de "Seyfi Baba"da olduğu gibi yaşlı kadının yoksulluğunu anlatırken aslında bir "farkındalık" yaratmak düşüncesiyle tasvir yapar. Böylece ülkeyi yönetenlerin milletine/ümmetine karşı olan sorumluluklarını, Hz. Ömer'in adaletine telmih yaparak yansıtır. Âkif, bu iki şiir üzerinden Müslümanlara, "Komşusu açken tok yatmamak" düşüncesini de hatırlatmak için mekânları mercek altına alır.

"Kocakarı ile Ömer"de, torunlarına taş kaynatan kadının fakirliğini tasvir ettikten sonra, ümmetin sorumluluğunu taşıyan Hz. Ömer'e yaşlı kadının nazarından; "İşitme sen de civârında inleyen elemi, / Medine halkını üryan bırak, Mısır'da dolaş... / Gaza! Gaza! diye git, soy cihânı, gel paylaş!” (Ersoy, haz. Düzdağ, 1999: 84) eleştirisini yapan şair, yöneticilere önce yönetiminden

3 Stendhal, "roman, büyük bir yolun üzerinde gezdirilen bir aynadır. Kâh göklerin maviliğini yansıtır, kâh yolun çukurlarında biriken çamuru!” der. Bkz. Stendhal 1979: 393.) 
sorumlu oldukları halkın karnını doyurup sonra fetih/gaza düşüncesine sahip olmaları gerektiği ikazında bulunur.

\section{1. İdeal/ İdealize ve Kutsal Mekânlar}

Yaşadığ coğrafyaya, milletine, dinine hatta tüm İslam âlemine karşı sorumluluk hisseden, kayg1 duyan, Müslümanların kalkınmasını isteyen Âkif' in günlük, sıradan hadiseler üzerinden mekân, olay ve kişilere odaklanarak tasvirler yaptığı bilinir. Şair, kimi zamansa bazı mekânların kudsiyeti altında Müslümanlara mesajlar verir. Bu yüzden bazı şiirlerinde mekânlar, gündelik gerçekliğin parçaları olarak natüralist bir gözle değil sahip olduğu "ideal” $i$ yansıtmak için "birleştirici”" bir güç olarak, idealize edilerek anlatılır.

Camiler, Âkif'in şiirinde İslâm inancının, birliğin ve medeniyetin tezahürüdür ve kutsal, ideal mekânlar olarak ilk sırada yer alırlar. Safahat'ın ilk şiirinin "Fatih Camii" şiiri olduğunu düşünecek olursak, şairin İslâm inancının ve medeniyetinin sembolü olan bu kutsal mekâna verdiği anlamı daha iyi anlayabiliriz. Cami üzerinden kimi zaman ümmetin ve çağın içinde bulunduğu yozlaşmışlığı tasvir eden Âkif, bu kutsal mekânın Müslümanları “birleştirici rolü”nü hatırlatarak göstermek ister. Fatih Camii’ne geçmişten geleceğe bir yolculuk yapan şair, şiirde camiyle medeniyeti, medeniyetin insanını, kendisini, kız kardeşini ve babasını anlatırken karanlık gecenin ardından doğan güneşin yavaş yavaş ağarttığı bu camiyle İslâm toplumuna karanlıklar içinden doğan İslâm güneşini hatırlatıyor gibidir:

"Yatarken yerde ilhâdıyle haşr olmuş sefil efkâr,

Yarıp edvârı yükselmiş bu müdhiş heykel-i ikrâr,

Siyeh reng-i dalâlet bir bulut şeklinde mâzîler,

Civârından kaçar, bulmaksızın bir lâhza istikrâr;

Ziyâ-rîz-i hakîkat bir seher tavrında müstakbel,

Gelir fevkınden eyler sermedî binlerce nûr îsâr" 
(Ersoy, haz. Düzdağ, 1999: 7)

"Fatih Camii”nin Müslümanlar için taşıdığı/taşıması gereken değeri, okuyucunun daha iyi anlamasına çaba sarf eden Âkif' için "Fatih Camii”, tıpk1 "Süleymaniye" gibi kitaplarına isimlerini de veren ideal/idealize mekânlardır. "Sine-i münevverine sokul"duğu bir ideal mekân olarak "Fatih Camii"nin heybetini, İslâm dünyası için taşıdığı kudsiyeti gözler önüne serer:

"Bu kudsî ma'bedin üstünde tâban fevc fevc ervâh

Bu ulvî kubbenin altında cûşan mevc mevc envâr.

(...)

Bu bir ma'bed değil, Mâ'bûd'a yükselmiş ibâdettir;

Bu bir manzar değil, dîdâra vâsıl mevkib-i enzâr.

Semâdan inmemiştir, şüphesiz, lâkin semâvîdir:

Zemînî olmayan bir cilve-i feyyâzı hâvîdir."

(Ersoy, haz. Düzdağ, 1999: 8-9)

Şair, Safahat'ın 2. kitabının adı olan "Süleymaniye Kürsüsünde" şiirinde de, aynı niyetle yapılmış mekân tasviri söz konusudur. Şiir, şairin mükemmel diliyle yaptığı bu kutsal mekânın dıştan ve içeriden tasviriyle başlar. Böylece yine caminin İslâm medeniyetini temsil ettiğine, birleştirici gücüne atıfta bulunan şair, dostunun ağzından dönemin Osmanlı toplumu ve diğer İslam diyarlarının o dönemdeki dinî, sosyal ve siyasal durumlarını masaya yatırır. Âkif, Süleymaniye camisini, abidevî fiziksel görünüşü kadar, İslâm dünyasına kattığı ebediyet ve medeniyet şuuru açısından da büyük bir saygıyla idealize ederek anlatır:

"Ne seher-pâre-i san'at ki ezelden mahmûr...

Leb-i deryâdan uçan bir ebedî hande-i nûr!

Sanki ummân-1 bekânın ezelî bir mevci,

Yükselirken göğe, donmuş da kesilmiş inci!..

Bu güher pârenin eb'âd-1 semâvîsinde" 
diyerek idealize ettiği ulu mâbedi, okuyucuya âdeta gezdirir gibi tasvir eder: “(...)Nereden? Haydi şadırvan kapısından girelim:

Bir musanna' kemer, üstünde kurulmuş Tevhîd;

Daha üstünde bir âyet ki: Hudâ' dan te'yîd,

Emr-i mevkût-i salâtın bize kat'iyyetine.

Şöyle bir baktı mı insan, kapının hey'etine ,

Evvelâ her iki yandan oluyor çehre-nümûn:

Mütenâzır iki mihrâb, iki âzâde sütûn.

Sonra göz yükseliyor doğru yarım kubbelere,

Ki dayanmış biri sağdan, biri soldan kemere.

(...)

Ma’bedin cebhe cidârındaki loş pencereler,

Güneşin sırtına bir ince tül atmış, esmer,

Mütemâdî sağıyor dâhile bir gölgeli nûr.

O inen perde-i seyyâl arasından manzûr,

Koca bir mahşer-i îman ki ezelden medhûş...

Sîneler vecd ile pür-cûş, dudaklar hâmûş!

Diz çöküp mermerin üstünde yalın kat hasıra,

Bekliyor hepsi münâcâtı: Onun şimdi sıra." (Ersoy, 1999: 143-144)

Şair, şiirde vermek istediği mesajı da; "O ziyâ âlemi bilmez ki karanlık ne demek; / O semâvî yuva kirlenmedi, kirlenmeyecek!” (Ersoy, 1999: 137-142) dizeleriyle okura yansıtmıştır. Bu dizede geçen "semavî yuva” ifadesi, şairin bu mekâna yüklediği "kutsal”, "ideal” sıfatlarını açıklar. "Şiirde, "Ey cemâat, uyanın! Yoksa, hemen gün batacak / Uyanın! Korkuyorum Leyl-i nedâmet çatacak" diyen Âkif, bu kutsal mekân üzerinden İslâm' dan uzaklaşmaları yine Müslümanları geleceğe dair endişeyle uyarmıştır. Şair, işgal ve savaş yıllarında da iki ideal mekânı olan Fatih Camii ve Süleymaniye Camii’nin birleştirici gücünden yararlanmış; bu ideal/kutsal mekânların taşıdıkları simgesel değerin de gücüyle Müslümanları birleşip savaşmaya davet etmiştir. 
1915'te Berlin'den döndükten sonra yine Teşkilat-1 Mahsusa tarafından Necid Emiri İbnürreşid'in yanına gönderilen Âkif, İslâm coğrafyasının kalbine yaptığı bu seyahatle Hz. Muhammed'in türbesini de ziyaret imkânı bulur. Safahat'ın beşinci kitabı Hatıralar'da yer alan 1915 tarihli "Necid Çöllerinden Medine'ye” başlıklı şiirinde, dünyada savaşın “yok edici”liği sürerken ziyaret ettiği bu kutsal topraklarda, savaşa rağmen hissettiği huzuru, sahip olduğu davanın eşliğinde mekânı idealize ederek sergiler. (Bu konuda bkz. İnan, 2014: 403-411). Şiirde, İslâm'ın beşiği olan çölün atmosferi karşısında kendinden geçen şair, çölün onu tıpk1 "Fatih Camii” şiirinde olduğu gibi vecd hâlinde betimler:

"Ne manzaraydı, İlâhî, o herc ü merc-i samut!

Ki vecde geldi semâdan ansizın melekût

Hurûş edip beşi birden yanık minarelerin, Hudâ'yı bağrına basmış yığın yığın beşerin

Gömülmüş olduğu ummânı dalgalandırdı" "San'atin sırrını ressâm-1 ezelden okuyan;

Rûh-i ma'sûmu bütün hilkati kendinde duyan;

Şimdi yerlerde şafak, şimdi bulutlarda bahar;

Şimdi tûfân-1 ziyâ, şimdi köpük, şimdi buhar;

Şimdi, mahmûr-i tefekkür, uzanan enginler;

Şimdi yalçın kayalar, şimdi oyulmuş inler;

Şimdi dalgın dereler, şimdi zılâl ummânı;

Şimdi bir vâha çizen; şimdi bütün elvânı

Toplayıp mâvi elekten geçirirken, üryan

Kumların üstüne bin türlü bedâyi' dokuyan

O güzel sîne, o çöl, şimdi ne korkunç oluyor:” (Ersoy, 1999: 307-308)

$\mathrm{Bu}$ şiirde de mekânın idealize edilerek anlatılması, şairin içindeki “İslâm dünyasını birleştirme, Hristiyan Batı'ya karşı İslâm davasına sahip çıkma" ideali"nin bir yansıması olarak anlaşılabilir. 
Âkif'in şiirlerinde idealize edilen bir başka mekân da, ruhunun huzur bulduğu "kabristan"dır. "Mezarlık" şiirinde Eyüp'te bir sabah ziyaret ettiği mezarlık atmosferini tasvir eden şair; bu mekânda, dünya ve zamanla olan bağlarını koparır. Fizikî âlem ile metafizik âlem (varlık ve yokluk) arasında hissettiklerini şöyle anlatır:

"Sıkınca rûhumu ba'zen metâlibiyle hayât,

Olur yegâne mesîrem mahalle-i emvât .

(...)

Ne levs-i hırs ü mezellet zemîn-i pâkinde,

Ne hây ü hûy-i maîşet harîm-i hâkinde,

Bu kâinât-1 huzûrun fezâ-yı sâmitini

Görünce, ömr-i perîşânımın merâretini,

Velev bir an için olsun atıp hayâlimden,

Uzaklaşır giderim mâsivâya artık ben.

Göründü karşıda füshat-serâ-yı kabristan.

Fakat o bir koca deryâ-yı sermediyyet idi, (...)

Ridâ-yı samte bürünmüş bütün yesâr ü yemîn ,

Huzûr içinde ağaçlar, sükûn içinde zemîn.

Bütün o yükselen emvâc, o bî-nihâye deniz,

Derin bir uykuya dalmıştı, her taraf sessiz.” (Ersoy, 1999: 38-39)

"Mezarlık”ta "Serviler Mevlâ’ya yükselmiş birer berceste âh" olarak tasvir edilir. Dünyadan ümidini kesen şair, sabah erken bir saatte ziyaret ettiği bu mekânda "öte" âleme geçmiş gibi mutludur ve tüm ümidi oradadır. "Sendedir ümmidler: Senden doğar fecr-i bekâ/ Ey semâvî hâk, benden bin selâm olsun sana" (Ersoy, 1999: 38) diyerek selamladığı bu mekâna hissettiği aidiyeti vurgular.

Benzer duyguyu bir seher vakti okunan ezanı dinlerken de hisseden şair, o atmosferde yaşadığı huzuru, inancı, beslediği ümidi, ezan öncesi ve 
sonrasındaki atmosferi tasvir ederek "Ezanlar" şiirinde yansıtır:

"Seher vaktinde mevcûdât, nûşîn hâb içindeyken,

Bu rûhânî nevâ, âfâkı mevcâ-mevc edip birden,

(...)

Bakarsin her taraf zulmet, fakat bir zulmet-i rûşen !

Semâ bîdâr, her yıldız Cemâlu'llâh'a bir revzen.

Güneş mağrib-güzîn olmuş, semâ esmer, ufuk gülgûn ;

Zaman durgun, zemin muğber cihan dembeste, can mahzûn;

Gariplik rû-nümâ yer yer, sükûnet dembedem efzûn ...

Bakarsın bir de gülbank-i İlâhî'den dolup gerdûn,

O tenhâyî-i sevdâvî olur Allah ile meskûn!

\section{(...)}

Ufukta yükselerek bir sadâ-yı dûrâ-dûr,

Yayıldı rûy-i zemînin o anda her yerine,

Sokuldu leyl-i ketûmun bütün serâirine.

Cihân-ı nâimi kaldırdı bî-karâr etti,

Zalâm içinde ne âlemler âşikâr etti! (Ersoy, 1999: 89-91)

Âkif'in yukarıda andığımız her biri işlevleriyle ve hissettirdiği ilahî duygularla "kutsal" olan mekânları, görünenin (somutun) ardındaki ideali yansıtmaları açısından önemlidir. Şark dünyasına yeniden İslâm idealini aşılamaya çalışan şair, cami gibi ebediyet ve medeniyet alanlarını "hatıllatıcı, birleştirici, harekete geçirici güç" olarak gördügü için kendi kutsallıkları yanında daha fazla idealize ederek anlatır. "Hakikî âlemin hatırlatıcısı" durumundaki "mezarlık" da, "bir Müslümanın bu dünyada ne için yaşayıp ne için ölmesi gerektiği" meselesini hatırlatmak için şairin idealize ettiği bir mekândır. 


\section{2. Kusurlu Mekânlar/ Batak Yuvaları:}

\section{Kahvehaneler, Meyhaneler}

Mehmet Âkif'in şiirlerinde somut olarak mevcut olan mekânlardan bir kısmı günlük hayatın sahneleri içinde yolukları ve bakımsızlıklarıyla tasvir edilirken bir kısmı da âdeta öfke ve tiksinti duyarak Müslümanları uzaklaştırmaya çalıştığı kusurlu mekânlar, batak yuvalarıdır.

Şairin "Mahalle kahvesi hâlâ niçin kapanmamalı? /Kapansın elverir artık bu perde pek kanlı!" diyerek öfke dolu mısralarla başladığı "Mahalle Kahvesi" şiiri, bir "batak yuvası" gibi gördüğü ve eleştirdiği bir kusurlu mekândır. Bu mekânı ve içinde uzun saatler geçirenleri, öfke ve alayla tahkiye eden Âkif, yine Müslümanlara uyarı ve telkinlerde bulunur.

"Mahalle Kahvesi"nde iç mekân tasvir edilirken her şey yırtık, kırık, eksik, pis ve âdeta bir "batak"1n parçaları gibi anlatılır. Kötü alışkanlıklar kazandıran bu mekândan Müslümanları uzak tutmak isteyen şair, onu özellikle karalayarak tasvir eder. Kahvenin daha kapısından girerken "Çamurlu bir kapı, üstünde bir değirmi delik;/Önünde tahta mı, toprak mı? Sorma, pis bir eşik" (Ersoy, haz. 1999: 103) diyerek okurda mekâna karşı olumsuz hisler uyandırmak ister. Şiirde mekân, "içindeki eşyalarla ve hatta canlılarla, çirkin bir resmin parçaları gibi anlatılır". (Bkz. Aydoğan, 1997: 96-97). Kahvehane içinde, ortada kara bacaklı bir mangal, peykelerin yanında sürüklenen kirli bir tomara benzetilen bir yatak ile üzerindeki yağlı pırtı, onun üzerine kurusun diye serilmiş yağlı mendil ve hasır sepetten söz edilir. (Bkz. Ersoy, 1999: 102-109)

Şairin birçok şiirindeki realist tasvirler, bakımsızlık ve pislik içinde betimlenen "Mahalle Kahvesi”nde de kendini gösterir. İstanbul'un yoksul mahallelerinden birindeki kahvehaneyi, tiksindirici ve şaşırtıcı görüntüleriyle alaya alan şair, her köşesini ayrıntılarıyla betimler. Tüm zamanlarını kahvede geçirenlerin aylak ve çirkin görüntüleri; kahvecinin kendi mesleği dışında halkı kandırarak (kan almak, diş çekmek vb. ) gayrı resmi işlerle de uğraşması, 
şairin yoğun gözlem ve tasvirleriyle alaya alınır. Şairin mekâna ayna tutarken sergilediği alaycı tutum tariz kabiliyetini de sergiler:

"Mühendis olmalı mutlak şu ak sakallı adam:

Zemîne dâire şeklindeki yaydı bir balgam;"

(Ersoy, haz. Düzdağ, 1999: 103) veya:

"Birinci katta sülük beslenen büyük kavanoz

Onun yanında kan almak için beş on boynuz

İkinci katta bütün kerpetenler, usturlar...

Demek ki kahveci hem diş tabibi, hem perukâr!

Sonunda bir ipe, boy boy, onar onar, dizilen,

Şu kazma dişleri sen mahya belledinse, değil”

(Ersoy, haz. Düzdağ, 1999: 104)

Âkif, bu şiirde tıpkı "Meyhane" şiirinde olduğu gibi mekânı ve onun yoğun gerçekçi tasvirini, cahil insanların "sürü psikolojisi"yle içine gömüldükleri yanlış eğilimleri sergilemek maksadıyla tercih etmiştir. Vaktin, paranın, emeğin ve ailenin kıymetini de hatırlatmak isteyen Âkif, şiirin içinde sıkça kullandığ “yı ğın” gibi kelimelerle, kahvedeki kitleye beslediği öfkeyi yansıtır. Öyle ki "tavanın pervazı altında gördüğü "çalışan kırlangıçlar”"1 da manzaraya dâhil ederek hesap sorar:

“Ayak teriyle cilâlanma tahta peykelere,

Külâhlı, fesli dizilmiş yığın yığın çehre:

(...)

Duyulmamış bu beyinlerde his denen meleke!

Tavanın pervazı altındaki toprak yuvadan,

Bakıyor bunlara, yan yan, iki çifte ince nazar:

"Ya sizin bir yuvanız yok mu?" diyor anlaşılan,

Dişi erkek çalışan yavrulu kırlangıçlar"

(Ersoy, Haz. Düzdağ: 1999: 107-108) 
Âkif'in "Bu, çehresindeki levsiyle yurda yüz karası" dediği 'Mahalle Kahvesi', âdeta okuyucuyu içinde yaşatacak kadar canlı biçimde (natüralist bir roman gibi) anlatılmıştır" (Fedai, 2008: 681). Aynı durum, "Meyhane" şiirinde de kendini gösterir.

Somut mekân olarak karşımıza çıkan "Meyhane", natüralist bir romanc1 dikkatiyle tasvir edilerek "batak yuvası"na benzetilir. "Meyhane"de, teneşirden yapılma masa, bacaksız iskemle, kırık dökük şişeler, çinko tepsi, tezgâh niyetine kullanılan yan çevrilmiş kirli sandıkla şair, natüralist bakış açısıyla sıfatlara anlam yükleyerek mekânı tasvir etmiştir. Böylece toplumun erkeklerine kötü alışkanlıklar kazandıran, yuvaları dağıtan bu tehlikeli mekâna karşı ikazda bulunmuştur. (Bkz. Ersoy, 1999: 32-36)

"Meyhane"de, İstanbul'un sokaklarında dolaşan ve cemiyetin sosyal manzarasını betimleyen şair, "Canım sıkıldı dün akşam, sokak sokak gezdim; Sonunda bir yere saptım ki, önce bilmezdim" diyerek o mekânın hayatında yer tutmadığına dikkat çeker. "Dikildi karşıma bir han kılıklı meyhâne" dediği bu mekânı yine tıpkı bir natüralist roman gibi çirkinlik ve batağıyla tasvir eder:

"Basık tavanlı, karanlık, sefil bir dükkân;

İçinde bir masa, yâhud civar tabutluktan

Atılma çok ölü görmüş acıklı bir teneşir!

Yanında hurdası çıkmış bir eski püskü sedir.

Sakat, bacaksız on, on beş hasırlı iskemle,

Kırık dökük şişeler, bir de çinko tepsiyle,

Beş on kadeh, iki üç testi... Sonra tezgâhlık

Eden yan üstüne devrilme kirli bir sandık.

Sönük sönük yanıyor rafta isli bir lâmba...

Önünde bir küme: Fes, takke, hırka, salta, aba”

(Ersoy, haz. Düzdağ, 1999: 32)

Menderes Coşkun da Âkif'in, "Meyhane", "Derviş Ahmet”, "Neyzen Tevfik", "Küfe", "Mahalle Kahvesi" gibi çoğunlukla sefalet veya sefahat 
içinde olan insanların hayatını anlattığı manzumelerinde, Zola ve Daudet gibi realist ve natüralistlerin izlerinin görülebildiği”"ni vurgulayarak görüşlerimize ortak olmuştur (Bkz. Coşkun, 2008: 560).

"Mahalle Kahvesi"nde olduğu gibi "Meyhane" de diş mekâna değil “iç”e odaklanan şair, bu şiirde Ömer, Hasan, Dimitri, Baba Arif gibi kişileri de mekâna ekler. Ayrıca içki sebebiyle bu mekânın yuvaları dağıtan yapısına ve ailenin kutsallığına dikkat çekmek için bir kocayı ve kocasını arayan bir kadını da şiire dâhil eder. Diyaloglarından kaygısız, tembel ve yozlaşmış olduklarını anladığımız meyhanenin müdavimleri, yarı karanlık, dumanlı meyhane atmosferi içinde yarına dair hiçbir amaca sahip olmayan, sefil ve hedonist insanlardır. Şair, bu amaçsız, hedonist insanların bu atmosferdeki âdeta kokuşmuş halleriyle, evlerinde ekmek bekleyen ailelerini önemsemeden, saatlerini içki masasında geçiren tembel Müslümanları eleştirmiştir. "Mahalle Kahvesi" gibi "Meyhane"nin de cemiyetin erkeklerinin ahlâklarının bozulmasına, yuvalarının dağılmasına neden olduğuna işaret etmiştir.

\section{3. İslâm Ülküsünün Geniş Mekânı: Şark Coğrafyası}

Âkif, fertten cemiyete (ümmete), dar mekândan (kahve, meyhane, cami, ev, mezarlık, sokak, şehir) geniş mekâna (vatan toprăğ, İslâm coğrafyası) kadar Şark'ın toplumunun gerçeklerini; Kur'an-1 Kerim'i, Hz. Muhammed'i rehber alarak, İslâm büyüklerine telmihte bulunarak yansıtmış inançlı bir sanatçıdır.

Şairin Mısır'da, memleketinden uzakta iken hissettiği hasret, bir mekâna ait olamama hissi, Müslüman Şark coğrafyasının davasına sahip çıkma kaygısıyla birleşerek daha yoğun şekilde Şark’1 uyarmaya çabalamasına neden olmuştur. Şair, bu psikolojiyle yazdığı şiirleri, 1933'te Mısır'da Arap harfleriyle yayınladığı Gölgeler'de toplamış; Safahat'ın bu son kitabında, iç dünyasının derinliklerini yansıttı̆̆ 1 gibi, “Şark coğrafyası”nın "garip”liğini de masaya yatırarak yine atmosfer üzerinden cemiyeti uyarıp düzeltmeye 
çabalamıştır. Âkif, Şark’a, bir başka Şark toprağından bakarken; şiirlerine yine hüzün ve öfke siner. Bu kitaptaki şiirlerinde de daha evvel yaptığı gibi Şark’’ bir coğrafyanın adı olarak değil her türlü zaafıyla "İslâm medeniyetinin aynası" olarak yansıtan şair; Şark'ın açmazlarına, sorumluluklarını unutan, idealinden uzaklaşan, "haz"a evrilen bakış açısına, cemaat olmaktan uzaklaşıp çevresiyle çatışan nefsine, mutad olmuş tembelliğine, çabuk kırılan şevkine ve her an dağılmaya müsait psikolojisine ayna/ projektör tutmuştur (Bu konuda bkz. Fedai, 2013: 62-69).

Hatıralar kitabındaki "Uyan" adlı şiirinde; "Ey koca Şark, ey ebedî meskenet! / Sen de kımıldanmaya bir niyyet et" (Ersoy, 1999: 266) diyerek Şark’1 "ebedî meskenet” olarak gören, Garp'tan gelecek tehlikelere karş1 kaygıyla uyaran Âkif, Gölgeler'de, kendi yalnız ve kırgın iç dünyasını da dışa vurarak "Şark”, “Alınlar Terlemeli”, "Umar Mıydın?” gibi şiirler yazar. Bu kitabındaki şiirler, şairin ruh hâliyle ve yalnızlığıyla da doğru orantılı olarak metafizik nitelikler de taşır. Doğu'nun dünyasında gözlediği realiteden dolayı öfke ve ümitsizlik duyduğundan, bakışlarını iç dünyasının derinliklerine çevirirken dünyadaki varoluş muhasebesini yapar.

Evvelce de ifade edilmeye çalışıldığı gibi, Mehmet Âkif, milleti/ ümmeti var eden unsurların toprak, din, bayrak olduğuna inanarak bu topraklara, sadece bir "coğrafya" parçası, üzerinde yaşanılan "mekân" duygusuyla yaklaşmamıştır. Hayatı boyunca bir "karakter abidesi” olarak yaşayan Âkif, şiirlerini büyük bir imanla bağlandığı Müslüman Şark medeniyetinin değerlerinin savunulmasına adamıştır. Lakin şiirlerinde "Şark coğrafyası" idealize edilen bir mekân olmamış yine eleştirilerek ve uyarılarak düzeltilmeye, değiştirilmeye çalışılan bir coğrafyadır.

Gölgeler kitabındaki 1918-1921 yıllarının atmosferini yansıtan "Bülbül” ve "Leylâ" gibi şiirlerinde de Âkif, Türk şiirinin iki önemli mazmunu, "Leyla" ve "Bülbül” üzerinden, işgal edilen vatan toprakları karşısında hissettiği derin üzüntüyü yansıtır. Şairin, kurtuluş umudunu "Leylâ" ile 
özdeşleştirmesi, bize "Hürriyer Kasidesi"nde vatanı nazlı, vefasız ve alaycı bir sevgiliye benzeten Namık Kemal'in tavrını anımsatır. Şair "Leylâ" şiirinin ilk dizesinde "toprak"a, bir aidiyet alanı olarak yer vermiş ve: "Barındırmaz misin koynunda, ey toprak?" derim, "yer pek"; (Ersoy, 1999: 431) dizesiyle, -Bülbül'de olduğu gibi- vatanın işgalinden dolayı duyduğu üzüntüyü toprağa sığınarak dindirmek istemiştir. Hissettiği utançtan dolayı toprağın kendini bağrında saklamasını istemiştir.

İslâm idealine, milletine ve toprağına karşı hissettiği sorumluluk duygusuyla Âkif, "Leylâ"dan yardım dilediği gibi, "Bülbül”e de içini döker. "Şark’ın vefasız, kansız evlâdı" olarak gördüğü kendi "ben”inin, "bütün yurdu Serâpâ Garb'a çiğnet”tiğini söyleyerek (Ersoy, 1999: 429-430) aslında vatansever, vicdanlı bir aydın sorumluluğuyla üzüntüsünü anlatır. Zira "Bülbül”ün de kıyametler koparırcasına inleme nedeni, "Salâhaddin Eyyûbî'lerin ve Fâtih'lerin yurdu"nun işgal altında olması ve düşman çizmeleri altında çiğnemesidir.

Mehmet Akif'in dostu Abbas Halim Paşa'nın davetiyle Mısır'a ilk gidişi sırasında yazdığı "El-Uksurda" şiirinde gezdiği yerleri fotoğraf gibi tasvir ettiği, anlar-ttığı atmosferden hoşnut olduğu görülür:

"Zemîne şimdi, o gündüz alev saçan,

Âfâk Ilık 1lık döküyor bir havâ-y1 istiğrâk.

Gülümsüyor yüzü artık muhît-i reyyânın, (...)

Gülümsüyor koca vâdî, gülümsüyor tepeler;

Gülümsüyor suyu tırmanmak isteyip öteden,

Uzun kürekli kayıklarla bir büyük yelken;

Gülümsüyor beriden gölgeler döküp Nîl'e,

Otel binâları etvâr-1 imtinânıyle;

Gülümsüyor kıyılardan beş altı hatve kadar, İçerde, ipli sırıklarla işleyen kuyular; 
Gülümsüyor suyu kırbayla aktaran fellâh ;

Gülümsüyor bunu ömründe görmeyen seyyâh;

$(\ldots)$

"Gülümsüyor diyorum koca bir mabedin uzakta yeri,

Gülümsüyor sağa baktıkça karşıdan "Karnak"

Gülümsüyor o sütunlar ki Nil’e müstağrak, (Ersoy, 1999: ).

1925 'te Misır'a ilk ziyaretini yapan Âkif'in, seyahat ederken gördüğü yerleri betimlediği bu şiirin devamındaki bölümde Mısır'ın İngilizlerce işgaline ve İslam dünyasının içinde bulunduğu duruma gözyaşı döktüğü görülür. Vatanından ayrı düşmüş bir insanın gariplik psikolojisiyle manzarayı görüp canı yanarak anlatan, tüm Şark’a Mısır'dan bakıp ağlayan şair, "Senin nerendeki evladının nasibi huzur?" diye sitem eder. (Bu konuda bkz. Kalyon, 2021: 13) İşgal edilen Mısır üzerinden tüm Şark için aynı tehlikenin var olduğunu bilerek üzüntü duymuştur:

"Evet bu sâha-i cûşun, bu cûş-1 ezvâkın

İçinde ben, yalnız ben zavallı gülmüyorum...

Oturmuş ağliyorum, ağlasam da ma'zurum,

Vatan-cüda gibiyim ceddimin diyârında!

Ne toprağında şu yurdun, ne cûybârında.

Bir âşina sesi, yâhut bir âşina izi var!

Sadâma beklediğim aksi vermiyor ovalar.

Bileydim ey koca Şark, ey cihân-1 durâdur,

Senin nerendeki evlâdının nasibi huzur? (Ersoy, 1999: 280).

Âkif, kendi içinde kavgalı ya da bölünmüş olan Müslüman Şark'ın durumuyla, Garp dünyasının durumunu da şiirlerinde zaman zaman karşılaş̧ırmıştır. $\mathrm{Bu}$ şiirlerde, Müslümanların sorumluluk yüklenmesi gerektiğini aksi takdirde durumun bir felâket olacağının ikazını yapan şair, etkiyi arttırmak için yine mekân ve tasvirden yararlanır. ("Şark", "Uyan", "Alınlar Terlemeli", "Hâlâ mı Boğuşmak?" vb.) Ancak tüm tasvirlerinde 
olduğu gibi bu tasvirleri de estetik bir amaca hizmet etmek için yapılmamış; insanın ve toplumun dramını yansıtmak, hakikatlerin önündeki sis perdelerini kaldırmak için yapılmıştır.

\section{3, Sonuç ve Değerlendirme}

"Nesnelerin canlılık bulması insan hayatıyla ilgileri ile mümkündür. Dolayısıyla tasvirin estetik olmaktan çok, insana ilişkin işlevsel bir anlamı olmalıdır" (Bkz. Fowler, 1991: 25) görüşü; sanat eseri üzerinden cemiyete dair kaygılarını yansıtan; eleştiri ve yönlendirmeleriyle onu değiştirip dönüştürmek isteyen, cemiyete idealini ve sorumluluklarını hatırlatmak isteyen sanatçılar için ayrı bir anlam taşır. Mehmet Âkif Ersoy'un şiiri için de, fertten cemiyete aşılanacak değerler, hatırlatılacak sorumluluklar için mekânların ve barındırdıkları nesnelerin reel tasvirleri hayatla olan bağlarını yansıtmak açısından oldukça önemlidir. Mehmet Âkif'in şiirlerinde üç ana başlık altında toplanabilecek mekânlar, (kutsal ve idealize mekânlarından, natüralist bir nazarla tasvir ettiği "kusurlu mekânlar"a ve İslâm ülküsünün taşıyıcısı durumundaki Müslüman Şark coğrafyasına kadar), fertten cemiyete yayılan sorumlulukları hatırlatma, değerleri telkin etme, eleştirerek dönüştürme amaçlarına hizmet eder.

Şairin, cami, mezarlık, türbe gibi "kutsal"/“ideal"/"idealize" mekânlarında huzur bulmuş kendi ruhu üzerinden Müslümanlara, uzaklaştıkları değerleri hatırlatmayı hedeflediği görülür. Natüralist romancıları aratmayan gerçekçi tasvirleriyle yansıttı̆̆ meyhane, kahvehane gibi "kusurlu” mekânlar, yoksul ev ve sokaklar, ikazlarda bulunarak Müslümanları bu mekânlardan uzaklaştırmak düşüncesine hizmet etmek için ayrıntıyla tasvir edilmiştir.

Sonuç olarak Âkif'in tüm Şark coğrafyasını mercek aldığı şiirlerinde; bu coğrafyanın tembellik, çekişme, uyuşukluk gibi eğilimlerini eleştirerek Müslüman Şark'a "ideal"ini hatırlatma düşüncesiyle mekâna odaklandığ1 söylenebilir. Böylece Şark’1 bir coğrafya parçası olarak görmeyen şairin, 
yaptığı tasvirlerle bu coğrafyanın mutad yaralarına neşter vurduğu anlaşılır. Şairin savaş temalı şiirlerinde ise, savaş atmosferini okuyucuya tüm vahşetiyle ve derinden yaşatma becerisi dikkat çeker. Fiziken yer almadı̆̆ı bir savaşı (Çanakkale Savaşı) dahi sanki savaşta bulunmuş gibi gerçeğe oldukça yakın biçimde tasvir edebildiğini gördüğümüz şairin, mekânı; inanç, aidiyet, sorumluluk ve ideal telkini için şiirlerinde natüralist bir romancıyı aratmayan gerçekçilikle tasvir ettiğini söyleyebiliriz. Bilhassa İstanbul'da gözleyip anlattığı mekânlarda "ideal" veya "kutsal" mekânlar olarak betimlediği camiler, İslâmın tüm dünyaya doğmasını arzu ettiği güneşi temsil edercesine sabahın ilk 1şıkları içinde tasvir edilir. Seher vakti silüeti beliren camiler (Fatih ve Süleymaniye), şair açısından İslâm'ın doğacak 1şı̆̆ı gibidir. Bazen de akşam vakti çıktığg yürüyüşlerde sokakların yoksulluğunu, bakımsızlığını, evlerinde kocalarının ekmek getirmesini bekleyen çaresiz kadınların veya yaşlıların hallerine tanıklık eden şair, cami, mezarlık gibi mekânlarda huzur bulurken kahvehane, meyhane gibi mekânlardan tiksinti duymuş ve bu hislerle mekân tasvirleri yapmıştır. Sanatını cemiyete adayan, hemen her şiirinde İslâm için kaygılanan Âkif, inançlı bir Müslüman'ın hissiyatıyla hareket etmiş; gerçekçi tasvirleriyle yansıttığı mekânlarda da aynı şuuru taşımıştır. Böylece Müslümanları cami gibi "ideal” mekânlara yaklaşmaya; "meyhane, kahvehane" gibi onları sorumluluklarından uzaklaştıracak mekânlardan sakınmaya davet ederken, bir Müslüman olarak sadece kendi hânelerinden değil aç yatan yoksul komşularının hânelerinden hatta tüm Müslüman Şark coğrafyasından sorumlu olduklarını hatırlatmak istemiştir. 


\section{Kaynakça}

AKYÜZ, Kenan (1986), Batı Tesirinde Türk Şiiri Antolojisi (1860-1923), İstanbul: İnk1lâp Kitabevi.

AYDOĞAN, Bedri (1997), "Mehmet Âkif Ersoy’un Meyhane ve Mahalle Kahvesi Şiirleri Üzerine Bir Değerlendirme”, Türkoloji Araştırmaları, Adana, s. 85-106

BOYNUKARA, Hasan (2007), "Mustafa Necati Sepetçioğlu'nun Bir Ömür Boyu Kıbrıs / Boyun Eğiş Romanında Tasvirler ve Tahliller”, Erdem, nr. 49, s. 289-296.

COŞKUN, Menderes (2008). "Mehmet Akif'in Şiir Anlayışı ve Şiir Seviyesine Yükselmiş Manzumeleri”, 1. Uluslararası Mehmet Akif Sempozyumu Bildiriler Kitabı. Burdur, s. 547-562.

ÇANTAY, Hasan Basri (1966), Âkifnâme (Mehmed Âkif), İstanbul: Ahmet Said Matbaas1.

ENGINÜN, İnci (1997), "Safahat'ta İstanbul'un Romanı", Vefatının 60. Yılında Mehmed Âkif Sempozyumu Bildirileri, İstanbul: İSAR Yayınları, s. 63-77.

ERSOY, Mehmet Âkif (1999), Safahat (Haz: M. Ertuğrul Düzdağ), İstanbul: Şûle Yayınları

FEDAİ, Özlem (2008), "Eşyaya Hakikati Söyletmek” Yahut Mehmet Akif Ersoy’un Şiirlerinde Tasvirin İşlevi”, 1. Uluslararası Mehmet Akif Sempozyumu Bildiriler Kitabı. Burdur, s. 677-686.

FEDAİ, Özlem (2013), “Mehmet Âkif'in Misır'daki Mağarasından Yansıyan: Gölgeler”, Mehmet Akifve Gölgeler Sempozyumu Bildirileri, İstanbul: TYB Yayınevi, s. 62-69.

FOWLER, D. P. (1991), "Narrate and Describe, The Problem of Ekphrasis", The Journal of Roman Studies, Vol. 81.

GÖKÇEK, Fazıl (2007), Mehmet Âkif’in Şiir Dünyası, İstanbul: Dergâh Yayınları

İNAN, Ruhi (2014), "Savaşın Gölgesindeki Metinler; Zeytin Dağı ve Necid Çölleri’nden Medine'ye”, International Journal of Language Academy, vol. 2/4, pp. 403-411.

KALYON, Filiz (2021), “Mehmet Âkif'in Mısır'da Yazdığı Şiirler Mehmet Akif'in Bazı Şiirlerinde Mısır Yansımaları”, New Era Internatıonal Journal Of Interdıscıplınary Socıal Researches, Y. 6, Vol. 7, s. 11-19.

KAPLAN, Mehmet (2014), Türk Edebiyatı Üzerinde Araştırmalar-2, 9.b., İstanbul: Dergâh Yayınları.

KARAKOÇ, Sezai (1974), Mehmed Âkif, 2. b., İstanbul: Diriliş Yayınları.

KORKMAZ, Ramazan (2007), "Romanda Mekânın Poetiği”, Edebiyat ve Dil Yazıları Mustafa İsen”e Armağan, (Haz. Aynur Kulhanlığlu, Süer Eker), Ankara: Grafiker Yayınları. 
KORKMAZ, Ramazan(2017), “Romanda Mekânın Poetiği”, Romanda Mekân, (Edt.: Ramazan Korkmaz, Veysel Şahin), Ankara: Akçă̆ Yayınları.

STENDHAL (Marie Henri Beyle) (1979), Kırmızı ve Siyah, (çev. Ş. Hulûsi), İstanbul: Ülkü Basım.

TEKIN, Mehmet (2011), Roman Sanatı, İstanbul: Ötüken Neşriyat.

Tevfik Fikret, 18 Şubat 1317/3 Mart 1902; Tanin, 1324/1908, nr. 1/1327, Rübab-ı Şikeste, Tanin Matbaası: İstanbul.

TUNCER, Hüseyin (1992), Tanzimat Edebiyatı (Arayışlar Devri Türk Edebiyatı-I), İzmir: Akademi Kitabevi.

UĞUR, Veli (2016), "Safahat'i Bakhtin'le Okumak", Uluslararası Sosyal Araştırmalar Dergisi, C. 9, S. 43, s. 462.

WEAVER, Raymond M. (1991), "What is Description?”, The English Journal, Vol. 8, No. 2 .

WELLEK, Réne - VARREN, Austin (1993), Edebiyat Teorisi, (çev. Ömer Faruk Huyugüzel), İzmir: Akademi Kitabevi. 